\title{
The World (of education, research and business) Is No Longer What We Imagined
}

\author{
A Review of: \\ Whiplash - How to Survive Our Faster Future \\ by Joi Ito and Jeff Howe \\ Publisher: Grand Central Publishing, New York, 2016 \\ ISBNs: 978-1-4555-4459 \\ Price: $\$ 28.00$
}

Whiplash is a term used to describe the strain caused by a sudden movement of the neck that tears its muscles and tendons, as in a car crash for example. It is also the most appropriate title of a remarkable new book about our fast changing world of education, research and business, authored by Joi Ito, the Director of the now famous Media Lab in MIT and Jeff Howe, Director of the Media Innovation Program at Northwestern University, in the USA. They describe our world that is changing at breakneck speed and rapidly becoming unrecognizable. Not surprisingly, their prescriptions for surviving this world are also quite unrecognizable today.

But why is our world changing so rapidly and unrecognizably? The reason seems to be that the human species is now on the verge of truly becoming a superorganism. Happily we have gained a pretty good understanding of superorganisms by studying insect societies. Ants, bees, wasps and termites organize themselves into societies with impressive levels of social organization and integration, division of labour and communication, paralleling if not better than our own societies (Gadagkar 2001). Insect societies constitute the most successful and dominant components of the terrestrial fauna, especially in many tropical forests. They build elaborate nests for themselves, with complex architecture designed for climate control and defence during warfare. They can organize hunting parties and capture prey much larger or more numerous than themselves and wage war with their neighbours of the same or related species. Some species of ants and termites practice agriculture,

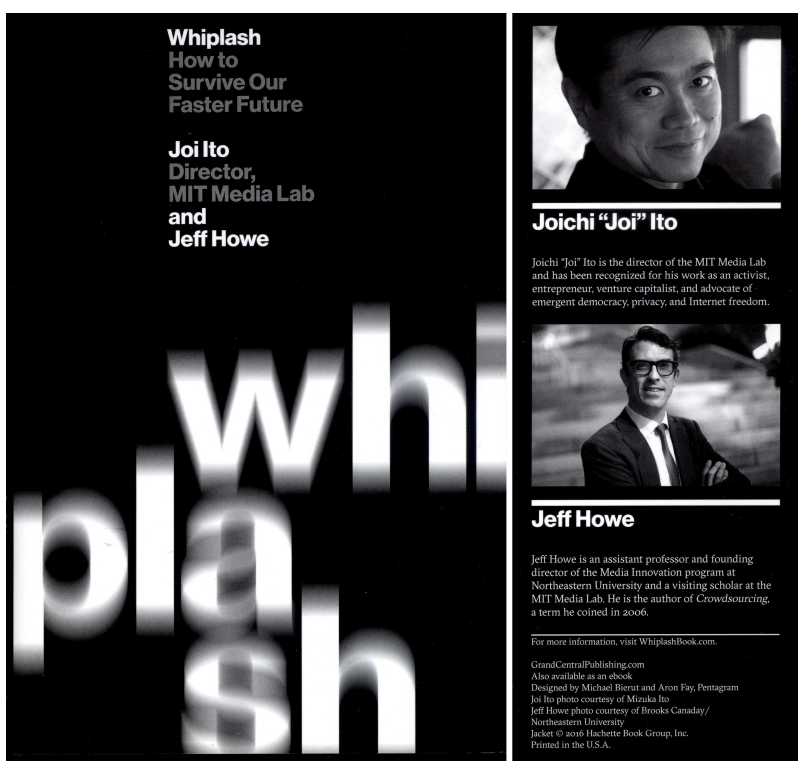

remarkably similar to and in many ways more resilient and sustainable than our own agriculture. Today we have moved away from naively admiring the amazing intelligence of these tiny creatures with brains no larger than a pin head. Instead we now realize that their remarkable feats are not the result of individual members of their societies being very intelligent but because they function as superorganisms (Hölldobler and Wilson 2009). They produce complex behaviours and patterns by self organization, be it nectar source selection by honey bees, trail formation in ants, swarm raids by army ants, colony thermoregulation by honey bees, building of mounds, walls and hexagonal combs by termites, ants, honey bees and wasps. Their complex patterns and behaviours emerge due to the

*Authorfor Correspondence: E-mail: ragh@ces.iisc.ac.in 
repeated actions of large numbers of individuals who follow simple rules and respond to local information only. No one has a global plan and there is no centralized or top-down control - it's all bottom-up. Intelligence, if there is any, is decentralized, often called swarm intelligence. Compared to what they can achieve as a group, the individual insects indeed appear rather stupid (Andrea and Theraulaz, 2017; Sumpter 2010).

With today's digital technology and wide-spread use of the internet, and especially the exponential growth of communication using Face Book, Twitter and WhatsApp, humans are able to communicate instantly with billions of people across the world and influence each other's behaviour in real time and on a global scale. This is resulting in unexpected and unplanned consequences, paralleling self-organization in insect societies. The behaviour of financial markets, current global communication patterns (Morales et al 2017) and even the growth of cities (Bettencourt 2013) are now best explained by considering bottom-up selforganization as the driving force. The rise to dominance of Wikipedia, Uber and Ola and the nascent results arising from crowd sourcing (Howe 2009), crowd funding and citizen science are already here as proof of principle (Libert et al 2017). This trend has only just begun and as it grows we can expect to see many more emergent phenomena, some constructive and some destructive. Add to this the growth of artificial intelligence and robotics and our imagination will cut loose. And it is not unreasonable to imagine that self-organization selects against individual intelligence; too much intelligence can come in the way of blind, repetitive actions that may be essential for self-organization to work. Indeed, a recent study has found that living in stable social groups is associated with smaller brain size in woodpeckers (Fedorova et al 2017). The era of individual geniuses such as Einstein, Darwin, Picasso, Mozart and Gandhi may be behind us. In this and the next century we may instead celebrate virtuoso networks or algorithms that produce new art and artefacts through selforganization, surpassing the capability of any individual genius in history.

How indeed can we survive in such a world. Perhaps we cannot, but we must prepare future generations to do so. It is here that the prescriptions of Ito and Howe become crucial. Their book is organized into nine chapters each espousing one of the principles on which the Media Lab in MIT is based. Invariably, these principles make conventional wisdom stand on its head. Thus they privilege emergence over authority, pull over push, compass over maps, risk over safety, disobedience over compliance, practice over theory, diversity over ability, resilience over strength and systems over objects. The tenth principle which runs throughout is to privilege learning over education. The words they choose to describe these principles are so evocative that one can begin to see where they are going with them, even without reading the book, provided of course one has the courage and ability to make conventional wisdom stand on its head. It might be worthwhile for readers to go through a mental exercise trying to imagine implementing each of their principles, before reading the relevant chapter. If you do so you would indeed be implementing the spirit of most of their principles already. Reading it after such reflection would bring even greater pleasure. The book is very fast paced as one might expect based on its subject matter; it can be read in almost one sitting, though at the risk of getting whiplashed!

Their prescriptions are so counter-intuitive that at first I wondered whether the world is ready for them, meaning of course whether the world is ready to survive. I was in a particularly pessimistic mood as I had recently watched a programme on NDTV in which Pranoy Roy interviewed Ruchir Sharma, the Chief Global Strategist and head of the Emerging Markets Equity team at Morgan Stanley, and author of The Rise and Fall of Nations (Sharma 2016). Ruchir Sharma described what he called the top ten global trends of 2017, which included to my horror, deglobalization and the death of outsourcing, declining faith in democracy and the rise of faith in authoritarianism, growing nationalism, and cracks in the tech space, expected to result in a slowing down of the tech industry worldwide. But deeper reflection suggests that these global trends have become a reality precisely because we have failed to adopt the principles espoused in Whiplash.

So how do we spread the word and prepare the world to adopt these shockingly counter-intuitive prescriptions. At least in the context of India I think we may nearly succeed if we incentivise at least two groups of people to read this book - high school kids 
and college students on the one hand and Departmental Chairs, Deans, Directors of Research Labs, ViceChancellors of Universities, Presidents of Science Academies, Secretaries of government departments concerning science and education and CEOs of Companies, on the other.

\section{References}

Andrea P and Theraulaz G (2017) When social behaviour is moulded in clay: on growth and form of social insect nests Journal of Experimental Biology 220 83-91 doi:10.1242/ jeb. 143347

Bettencourt L MA (2013) The Origin of Scaling in Cities Science 340 1438-1441 [doi: 10.1126/science.1235823]

Fedorova N, Evans C L and Byrne R W 2017 Living in stable social groups is associated with reduced brain size in woodpeckers (Picidae) Biol Lett 1320170008.

http://dx.doi.org/10.1098/rsbl.2017.0008

Gadagkar R (2001) The Social Biology of Ropalidia marginata-
Toward Understanding the Evolution of Eusociality Harvard University Press

Hölldobler B and Wilson EO (2009) The Superorganism - The Beauty, Elegance and Strangeness of Insect Societies W. W. Norton \& Company

Howe J (2009) Crowdsourcing: Why the Power of the Crowd Is Driving the Future of Business Crown Business

Libert B, Wind Y and Beck M (2017) What Airbnb, Uber, and Alibaba Have in Common https://hbrorg/2014/11/whatairbnb-uber-and-alibaba-have-in-common

Morales A J, Vavilala V, Benito R M and Bar-Yam Y 2017 Global patterns of synchronization in human communications $J$ R Soc Interface 14 20161048. http://dx.doi.org/10.1098/ rsif.2016.1048

Sharma R (2016) The Rise and Fall of Nations: Forces of Change in the Post-Colonial World WW Norton and Company

Sumpter D J T (2010) Collective Animal Behaviour Princeton University Press, New Jersey.

Raghavendra Gadagkar Centre for Ecological Sciences and Centre for Contemporary Studies Indian Institute of Science, Bangalore, 560012, India 